\title{
Medication treatment of alcohol use disorders in veterans with Hepatitis C
}

Peter Hauser

From $1^{\text {st }}$ International Congress on Neurobiology and Clinical Psychopharmacology

and European Psychiatric Association Conference on Treatment Guidance

Thessaloniki, Greece. 19-22 November 2009

Hepatitis $\mathrm{C}$ viral infection $(\mathrm{HCV})$ is the most common chronic blood borne viral infection in the world and in the United States affects approximately $1.8 \%$ of the general population. The prevalence of hepatitis $C$ viral infection $(\mathrm{HCV})$ is 3-4 times higher among veterans who use VA services than the general population rate of $1.8 \%$ and is estimated to be approximately 5 to $6 \%$. A national VA study found that over $75 \%$ of veterans had some Substance Use Disorder. At the Portland VAMC, $57.6 \%(n=783)$ of veterans with HCV recently seen in the hepatology clinic reported consuming alcohol in the past year and approximately $25 \%$ reported heavy alcohol use (AUDIT C score of 4 or greater).

Alcohol use and HCV are thought to act synergistically to accelerate liver damage and cirrhosis. Several studies show heavy alcohol consumption increases the risk of fibrosis progression as well as the risk of end stage liver disease and cirrhosis in HCV patients. Among them Corrao and Arico (1998) found, among all patients who do not drink alcohol, HCV-infected patients are 9.2 times more likely to develop liver cirrhosis than non-HCV-infected patients. They also found that there is a dose-dependent relationship between lifetime daily alcohol intake, $\mathrm{HCV}$ infection, and risk of developing cirrhosis. Compared to $\mathrm{HCV}$ patients who do not drink, the risk of cirrhosis was three times higher in $\mathrm{HCV}$ patients who drank 75 to 100 grams per day, 16 times higher in HCV patients who drank $\geq 175$ grams per day of alcohol than HCV patients who did not drink and over 140 times higher than people who did not have HCV or drink alcohol.

Effective treatments for alcohol use have not been studied in patients chronically infected with HCV and current FDA-approved medications for AUD can adversely

VISN 22 Mental Health Services Lead, Long Beach VA Medical Center, Long Beach, California, USA affect the liver and are generally not well tolerated. The presentation will review current FDA -approved as well as off-label use medication studies for Alcohol Use Disorders and their utility for people who have hepatitis $\mathrm{C}$ and co-morbid Alcohol Use Disorders. The various treatment options will be discussed.

Published: 22 April 2010

doi:10.1186/1744-859X-9-S1-S80

Cite this article as: Hauser: Medication treatment of alcohol use disorders in veterans with Hepatitis C. Annals of General Psychiatry 2010 9(Suppl 1):S80.
Submit your next manuscript to BioMed Central and take full advantage of:

- Convenient online submission

- Thorough peer review

- No space constraints or color figure charges

- Immediate publication on acceptance

- Inclusion in PubMed, CAS, Scopus and Google Scholar

- Research which is freely available for redistribution

Submit your manuscript at www.biomedcentral.com/submit
C Biomed Central 